\title{
Spectrophotometric Determination of Chlorocresol via Nitrosation Reaction - Application to Pharmaceutical Preparations (Creams)*
}

\author{
Nief R. Ahmed \\ Widad E. Hassan \\ The State Company for Drug Industries And Medical Appliances \\ Mosul - Iraq
}

(Received 10/11/2008; Accepted 1/6/2009)

\begin{abstract}
A spectrophotometric method for the determination of pure chlorocresol and in a number of its pharmaceutical preparations (creams) has been developed that offers advantages of simplicity, sensitivity and stability. The proposed method was based on the formation of a nitroso derivative of chlorocresol. The colored product have maximum absorption at $424 \mathrm{~nm}$. Beer's law is obeyed over the concentration range of (2-26) ppm, with a molar absorptivity of $0.417 \times 10^{4} 1 . \mathrm{mol}^{-1} \cdot \mathrm{cm}^{-1}$. Relative standard deviation of the method was better than $\pm 1.8 \%$ and the average recovery was $99.2 \%$. The proposed method has been successfully applied to the determination of chlorocresol in pure form and in pharmaceutical preparations (creams).
\end{abstract}

Keywords: Chlorocresol, Spectrophotometry; Nitrous acid.

\section{القير الاليف الكلوركربزط عنطرق قلبق فالى النترزةفي المستضرات الدوائية (الكربمكت)}

\section{المالخص}

يعتمد البحث على قطويرطريقةطيفية جديدة لقنير الكلوروكريزول بحالته القية وفي عدد مـ ن

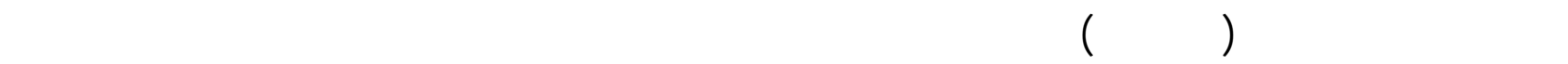

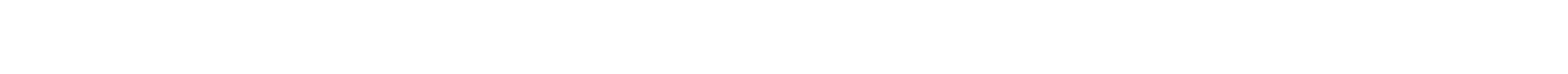

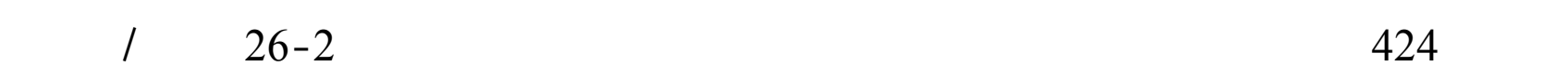

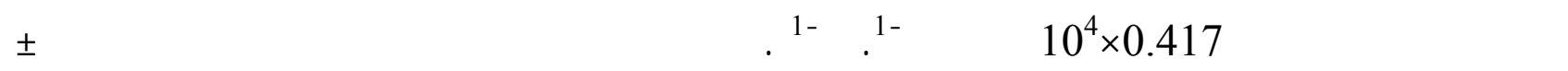

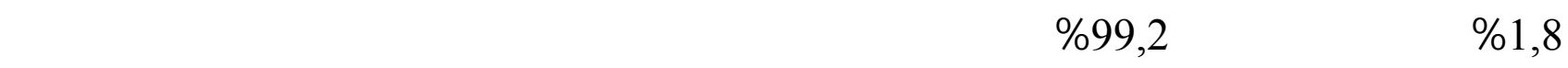
بعاض مستحضراته الصيدلانية (الكريملت).

*م إقاعه في المؤتمر العلمي الأول للكيمياء المنعد بتاريخ 22 -23 نيسان 2008 فى قسم الكيمياء /كلية العلوم/جلمعة الموصل 


\section{INTRODUCTION}

Chlorocresol (4-chloro-3-methylphenol) is widely used as a preservative and germicide in creams and other preparations for external use which contain water, but its effectiveness was reduced if oils, fats, or non-ionic surface active agents were present (The pharmaceutical codex,1979). Also, it was used as external germicide, as preservative of glues, gums, paints, inks, textile and leather goods (Wawley,1981). Chlorocresol is generally determined by chromatographic method (Tripathi et al.,1990 and Paul et al.,1999, Marengo et al., 2001 and Gatti et al.,1997) and the official indirect titrimetric method (British pharmacopoeia, 2005and The United States Pharmacopoeia, 2003). Other methods are polarographic method (Rao et al.,1990) and enzyme-amperometric which compared favorably with those found by using classical HPLC or spectrophotometric method (Bloofidel and Prebble,1992).

Very few spectrophotometric methods have been reported for chlorocresol determination(Ahmed and Ibrahim, 2004 and Campanella et al., 1992). In general, spectrophotometric methods require less expensive instrumentation than polarographic and HPLC methods (Paul et al.,1999 and Rao et al.,1990) which are widely used for the determination of chlorocresol. Therefore the research work in this paper is being directed to an approach in the spectrophotometric method for the determination of chlorocresol in pure form and a number of its pharmaceutical preparations.

\section{EXPERIMENTAL}

\section{Apparatus}

Spectro-scan 50 uv-visible spectrophotometer with 1- cm quartz cells was used for absorption measurements.

\section{Reagents}

All chemicals used were of analytical grade.

Chlorocresol standard solution $\left(100 \mathrm{ppm}\right.$ or $\left.7 \times 10^{-4} \mathrm{M}\right)$ : This solution was prepared by dissolving $(0.1 \mathrm{~g})$ of chlorocresol (Merck) in $1 \mathrm{~L}$ distilled water.

Sodium nitrite solution (3\%). This solution was prepared by dissolving $3 \mathrm{~g}$ of sodium nitrite in $100 \mathrm{ml}$ of distilled water.

Sodium hydroxide solution $(2 \mathrm{~N})$. This solution was prepared by dissolving $8 \mathrm{~g}$ of sodium hydroxide in $100 \mathrm{ml}$ of distilled water. from the above solution $(1 \mathrm{~N}) \mathrm{NaOH}$ solution was prepared.

Nitric acid solution $(5 \mathrm{~N}$ and $1 \mathrm{~N})$

\section{Recommended procedure}

An aliquot of standard solution of chlorocresol $(50-650 \mu \mathrm{g})$ were transferred into a serious of boiling test tubes. To each test tube, $1 \mathrm{ml}$ of $1 \mathrm{~N} \mathrm{HNO}_{3}$ and $1 \mathrm{ml}$ of $3 \% \mathrm{NaNO}_{2}$ were added, mixed well and placed on a water bath maintained at $80 \pm 5 \mathrm{C}^{\circ}$ for $10 \mathrm{~min}$. The solutions were cooled to room temperature and transferred to $25-\mathrm{ml}$ standard volumetric flasks, then $3 \mathrm{ml}$ of $1 \mathrm{~N} \mathrm{NaOH}$ was added. The contents were diluted to the volume with distilled water. The absorbances were measured at $424 \mathrm{~nm}$ against a reagent blank. 
Procedure for the determination of chlorocresol in pharmaceutical preparations (creams)

A quantity of creams equivalent to $0.01 \mathrm{~g}$ of chlorocresol was accurately weighed into $100 \mathrm{ml}$ flask, $50 \mathrm{ml}$ of $2 \mathrm{M} \mathrm{NaOH}$ solution was added and shaken until the solid dispersed. The content was mixed well and filtered using a Wnatman No. 42 filter paper. The filtrate neutralized by $5 \mathrm{~N} \mathrm{HNO}_{3}$. The volume was finally adjusted to $100 \mathrm{ml}$ in a volumetric flask by distilled water. A $6 \mathrm{ml}$ of this solution was treated as mentioned under the recommended procedure.

\section{RESULTS AND DISCUSSION}

\section{Absorption spectra and effect of experimental variables}

The absorption spectra of colored product shown in Fig.(1) is made on a solution containing $300 \mu \mathrm{g}$ of chlorocresol, $1 \mathrm{ml}$ of $\mathrm{HNO}_{3}, 1 \mathrm{ml}$ of $\mathrm{NaNO}_{2}$. The flask was immersed on a water bath maintained at $80 \pm 5 \mathrm{C}^{\circ}$ for $10 \mathrm{~min}$, the solution was cooled to room temperature, then $3 \mathrm{ml}$ of $1 \mathrm{~N} \mathrm{NaOH}$ was added and transferred to $25 \mathrm{ml}$ volumetric flask. The content were diluted to volume with distilled water. The absorption spectra of the product against blank was recorded. The colored product showed maximum absorption at $424 \mathrm{~nm}$ and this wavelength was recommended for determination.

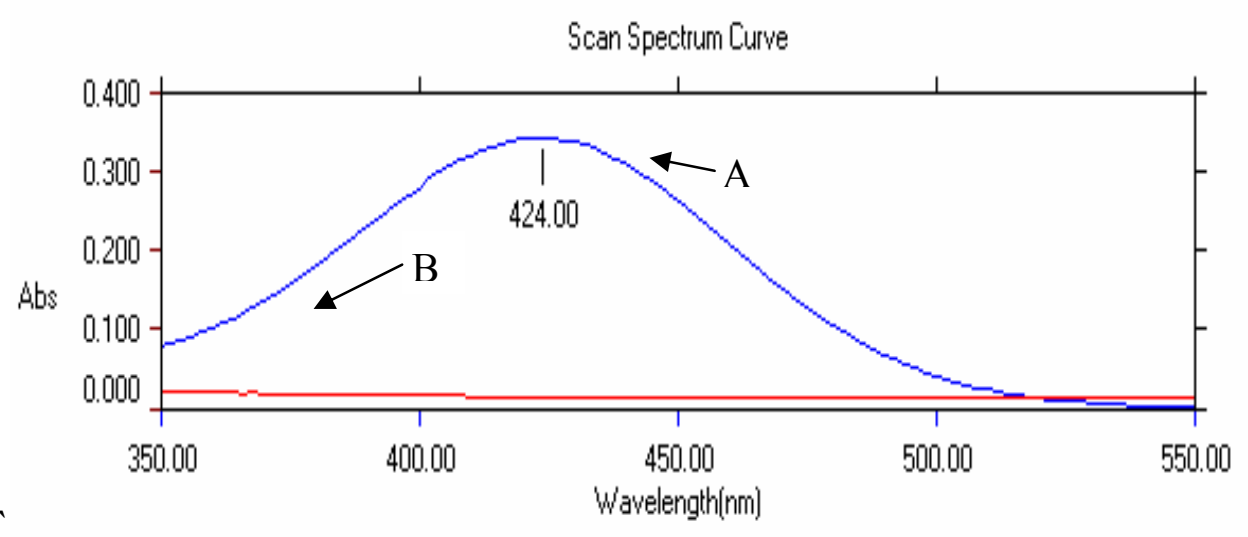

Fig. 1: (A) Absorption spectra of colored product against reagent blank, (B) blank against distilled water

\section{Study of the optimum reaction conditions}

The effect of various parameters on the absorption of the product formed was studied and the reaction conditions are optimized. 


\section{Effect of acid}

The effect of different acids on the absorbance of the colored product is shown in Table (1), which shows that maximum intensity was reached when using $1 \mathrm{ml}$ of $1 \mathrm{~N}$ nitric acid solution. This amount was selected for the subsequent experiments.

Table 1: Effect of acids on the absorbance

\begin{tabular}{|c|c|c|c|c|c|}
\hline Acids (1N) & \multicolumn{5}{|c|}{ Absorbance / ml of acid added } \\
\cline { 2 - 6 } Solutions & $\mathbf{0 . 1}$ & $\mathbf{0 . 5}$ & $\mathbf{1}$ & $\mathbf{2}$ & $\mathbf{5}$ \\
\hline $\mathrm{HCL}$ & 0.059 & 0.115 & 0.142 & 0.071 & 0.051 \\
$\mathrm{H}_{2} \mathrm{SO}_{4}$ & 0.070 & 0.142 & 0.168 & 0.072 & 0.063 \\
$\mathrm{HNO}_{3}$ & 0.117 & 0.204 & 0.248 & 0.163 & 0.058 \\
$\mathrm{H}_{3} \mathrm{PO}_{4}$ & 0.067 & 0.087 & 0.120 & 0.167 & 0.117 \\
\hline
\end{tabular}

\section{Effect of sodium nitrite reagent}

The effect of the amount of $\mathrm{NaNO}_{2}$ solution on the absorbance of the colored product was studied. It was observed that the addition of $1 \mathrm{ml}$ of $3 \% \mathrm{NaNO}_{2}$ solution was required to obtain a maximum absorbance. This amount was selected for subsequent experiments.

\section{Effect of temperature and heating time}

The effect of heating time on the color intensity was studied, in practice the absorbance of the color increases with increasing temp erature and reached maximum at temperature greater than $70 \mathrm{C}^{0}, 80 \pm 5 \mathrm{C}^{\circ}$ was selected. However, the reaction is complete within $10 \mathrm{~min}$. The absorbance was then stable for at least $6 \mathrm{hr}$. the effect of heating time and temperature is shown in Table(2).

Table 2 : Effect of temperature and heating time

\begin{tabular}{|c|c|c|c|c|c|c|c|c|c|c|c|c|}
\hline Temp. $\mathrm{C}^{\circ}$ & \multicolumn{3}{|c|}{40} & \multicolumn{3}{|c|}{60} & \multicolumn{3}{|c|}{70} & \multicolumn{3}{|c|}{80} \\
\hline Time(min) & 5 & 10 & 15 & 5 & 10 & 15 & 5 & 10 & 15 & 5 & 10 & 15 \\
\hline Absorbance & 0.138 & 0.140 & 0.142 & 0.258 & 0.260 & 0.264 & 0.320 & 0.324 & 0.324 & 0.336 & 0.340 & 0.340 \\
\hline
\end{tabular}

\section{Effect of $\mathrm{NaOH}$ concentration}

The amount of $\mathrm{NaOH}$ solution for maximum color intensity was examined. The maximum constant color intensity was reached when using $3 \mathrm{ml}$ of $1 \mathrm{~N} \mathrm{NaOH}$ solution. This amount was selected for subsequent experiments.

\section{Effect of order of addition}

To test the effect of order of the addition of the reagents on the absorbance of the product, different orders were tested. The selected order was chlorocresol solution, $\mathrm{HNO}_{3}$ solution followed by $\mathrm{NaNO}_{2}$ solution then heating and cooling then $\mathrm{NaOH}$ solution is added. This order gives the highest absorbance value.

[Chlorocresol $+\mathrm{HNO}_{3}$ solution $+\mathrm{NaNO}_{2}$ heating then cooling $\left.+\mathrm{NaOH}\right]$ 


\section{Beer's Law}

Under the recommended conditions described above, a linear calibration graph was obtained for chlorocresol within concentration range of $50-650 \mu \mathrm{g} / 25 \mathrm{ml}$. Linear regression equation : $\mathrm{A}=0.033+0.097 \mathrm{C}(\mathrm{r}=0.9998, \mathrm{n}=7)$ where $\mathrm{A}$ is the absorbance and $\mathrm{C}$ is the concentration in $\mu \mathrm{g} / \mathrm{ml}$. The molar absorptivity was $0.417 \times 10^{4} 1 . \mathrm{mol}^{-1} . \mathrm{cm}^{-1}$ and the limit of detection was evaluated as (Bassaviah, and Smoashekar, 2007 and International Conference.....) :

$$
L O D=3.3 \frac{\sigma}{S}
$$

Where " $\mathrm{S}$ is the slope and $\sigma$ is the standard deviation of the regression line. The limit of detection was $0.042 \mu \mathrm{g} / \mathrm{ml}$

Calibration graph of chlorocresol is shown in Fig (2).

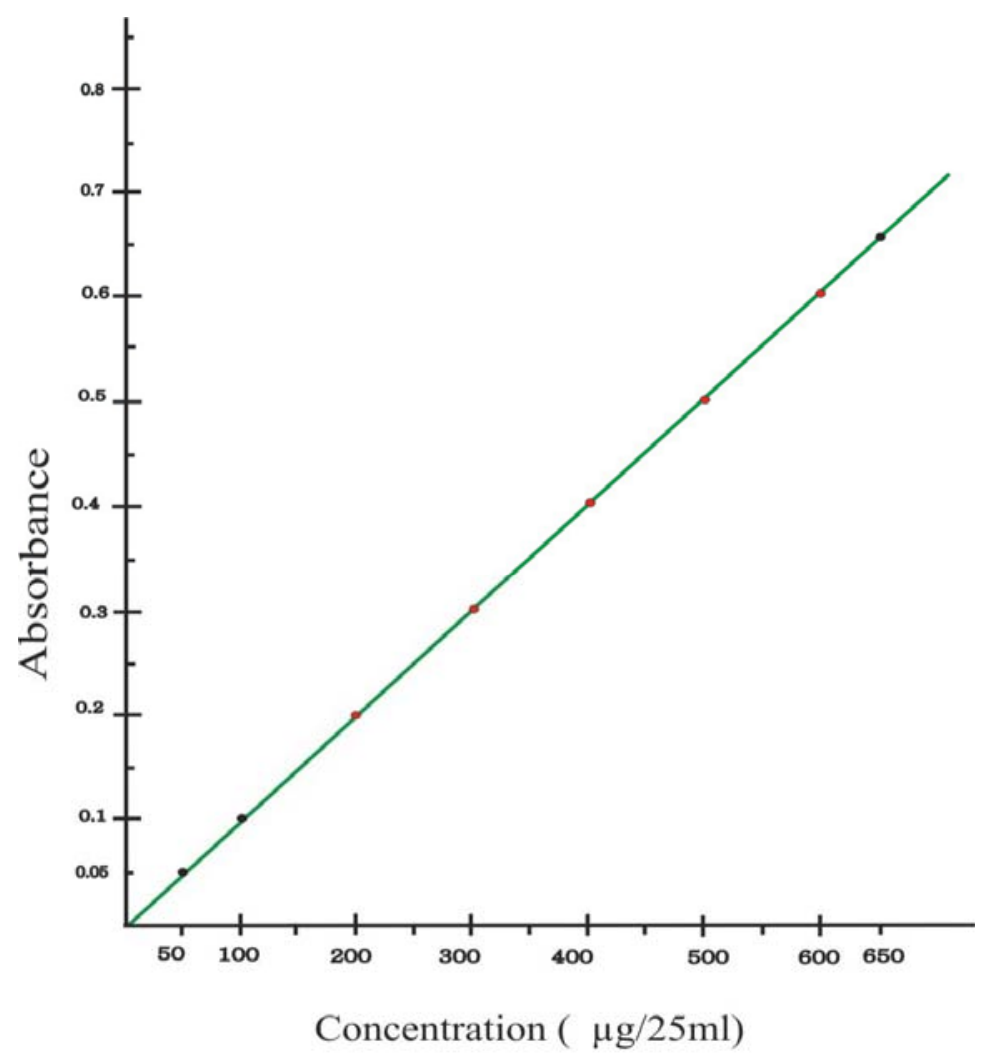

Fig[2]Calibration graph of chlorocresol

\section{Accuracy and precision}

The five independent analysis of chlorocresol samples at three different concentration levels $(100,200$, and $400 \mu \mathrm{g} / 25 \mathrm{ml})$ were performed. The relative standard deviation was found better than $1.8 \%$ and the accuracy (average recovery) was found $99.2 \%$. These results were quite satisfactory. 


\section{Composition of the colored product}

The stoichiometry of reactants was investigated by the mole- ratio method (Bauer et al., 1978). The results obtained indicated that the existence of 1:1 chlorocresol $-\mathrm{NaNO}_{2}$ at $424 \mathrm{~nm}$. Thus the suggested reaction might be written as (Belal et al., 1979).<smiles>CC1=CC(=O)C(=N[O-])C=C1Cl</smiles>

Chlorocresol

\section{Apparent stability constant of the product}

The conditional stability constant of the product is estimated by using Vargas method ( Gareia et al., 1981) with the following equation:

$$
K=\frac{a-(\Delta A / E)}{n^{n}(\Delta A / E)^{n+1}}
$$

Where : $\mathrm{a}=$ chlorcresol total concentration.

$\Delta A=$ sample absorbance in reagent excess minus the sample absorbance in stoichiometric reagent amount.

and $\quad \mathrm{n}=$ number of ligand.

$$
\epsilon=\text { molar absorptivity at the measured wavelength. }
$$

The stability constant ( mean of five values ) is found to be $4.3 \times 10^{5} 1 . \mathrm{mol}^{-1}$, indicating that the product is stable.

\section{Effect of interferences}

In order to assess the possible application of the proposed method, the effect of substances that often accompany chlorocresol in various creams was studied by adding different amounts of substance to $300 \mu \mathrm{g} / 25 \mathrm{ml}$ of chlorocresol. An attractive feature of the method is its relative freedom from interference by the usual diluents and excipients in amount far in excess of their normal occurrence in pharmaceutical preparations. The results are given in Table (3).

Table 3 : Determination of chlorocresol in presence of Interferences

\begin{tabular}{|l|c|c|}
\hline Interferences substance & $\begin{array}{c}\text { Amount taken } \\
(\mathrm{mg})\end{array}$ & Average recovery \% \\
\hline Betamethasone 17 valerate & 1 & 100.05 \\
\hline Clobetasol propionate & 5 & 100.00 \\
\hline Clotrimazole & 1 & 100.03 \\
\hline
\end{tabular}

*Average of three replicate analyses 


\section{Analytical Application}

Three types of creams containing chlorocresol ( Betnosam, Dermodin, and Fugidin ) were analyzed. The results were compared statistically by student $t$-test and by the variance ratio F-test with those obtained by official method at $95 \%$ confidence level. The calculated $\mathrm{t}$ - and $\mathrm{F}$ - values did not exceed the theoretical values indicating that there was no significant differences between the precision of the proposed and official methods as cited in Table (4)

Table 4: Determination of chlorocresol in pharmaceutical preparations (cream)

\begin{tabular}{|c|c|c|c|}
\hline $\begin{array}{c}\text { Type of creams } \\
\text { supplied by NDI }\end{array}$ & \multicolumn{3}{|c|}{ Amount of chlorocresol } \\
\cline { 2 - 4 } & Present method & $\begin{array}{c}\text { B.P } \\
\text { Official method }\end{array}$ & Certified value \\
\hline Betnosam & $\begin{array}{c}0.098 \% \\
\mathrm{t}=1.34, \mathrm{~F}=1.32 \\
0.148 \%\end{array}$ & $0.099 \%$ & $0.100 \%$ \\
Dermodin & $\mathrm{t}=1.84, \mathrm{~F}=1.09$ & $0.15 \%$ & $0.150 \%$ \\
& $\begin{array}{c}0.097 \% \\
\text { Fugidin }\end{array}$ & $0.095 \%$ & $0.100 \%$ \\
& $\mathrm{t}=1.55, \mathrm{~F}=1.42$ & & \\
\hline
\end{tabular}

- Mean of ten determinations.

$$
\begin{array}{lll}
\mathrm{t}=1.34 & , & \mathrm{~F}=1.32 \\
\mathrm{t}=1.84 & , & \mathrm{~F}=1.09 \\
\mathrm{t}=1.55 & , & \mathrm{~F}=1.42
\end{array}
$$

$\mathrm{t}$ values $(\mathrm{n}=10$, at $95 \%$ confidence level tabulated value 2.262

F values $\left(n_{1}\right.$ and $n_{2}=10$, at $95 \%$ confidence level tabulated value 3.18

\section{REFERENCES}

Ahmed, N.R. ; Ibrahim, F.K.(2004). Spectrophotometric determination of chlorocresol with p- aminophenol. J. Edu. Sci., 16, 97-102

Bassaviah, K. ; Somashekar, B.(2007). Quantitation of rantidine_in pharmaceuticals by titrimetry and spectophotometry using dichromate as the oxidimetric reagent, $J$. Iran. Chem. Soc., 4, 78-88

Bauer, H. H., Christian, G.D.; Oreilly, J. E. (1978)." Instrumental Analysis", Allyn and Bacon, Inc. Boston, pp.178-179

Belal, S. F.; Elsayed, M.; Elwalily, A. ; Abdine, H. (1979). Spectrophotometric determination of acetaminophen and salicylamide through nitrosation and subsequent chelation, Analyst,104, 919-927

British pharmacopoeia. ( 2005), Volume 1,350p.

Campanella, L; Sammartino, MP; Sbrilli, R. ; Tomassetti, M.( 1992). Analytical comparison of an enzyme- amperometric method for chlorocresol determination in ointment with colorimetry and liquid chromatography. J. Pharm. Biomed. Anal. ,10, 751-755

Gareia, M., Vargas ; Toro, P.D.(1981). Analyytical possibilities of pyridine -2-acetaldehyde benzyl hydrazone chromogenic reagent. Microchem. J., 26, 557-568 
Gatti, R.; Roveri, P. ; Bonazzi, D.(1997). HPLC- flourescence determination of chlorocresol and chloroxylenol in pharmaceuticals. J. Pharm. Bio. Analysis, 16, 405-412.

"International conference on hormonisation of technical requirement for registration of pharmaceuticals for human use ich harmonised tripartite guideline". Validation of analytical procedures : text and methodology $\mathrm{Q}_{2}(\mathrm{RI})$, complementary guideline on methodology dated 06 November 1996, incorporated in November 2005. London.

Marengo, E.; Gennaro, M. ; Gianotti, V.(2001). A simplex-optimized chromatographic separation of fourteen cosmetic preservatives: Analysis of commercial product. $J$. Chrom. Sci., 39, 339-344.

Paul, A.; Brooks, A. ; William, J.(1999). 4-Chloro-m-cresol triggers malignant hyperthermia in subceptible swine at doses greatly exceeding those found in drug preparations. Anesthesiology, 90, 1723-1732

Rao, N.V.; Tripath, A.M. ; Mhalas, J.G.(1989). Determination of 2,6 and 4,6 dinitro cresol by differential- pulse polarography. Microchem. J., 40, 251-256: Anal. Abst., 1990. 5C30

"The Pharmaceutical Codex",(1979).11th edn., London. 174 p.

The United States Pharmacopoeia (2003). 26, NF 21.

Tripathi, A. M.; Mhalas, J.G. ; Rao, N.V.( 1989). Determination of 2,6-dinitrocresol by HPLC on a B-cyclodextrin-bonded coloumn. J. Chromatogr, 466, 442-445: Anal. Abst, 1990.5C29.

Wawley, G.G.( 1981). "The Condensed Chemical Dictionary", 10th edn. Van Nostrand Reinhold Company, New York, 238 p. 